\title{
AAC Oravena oat
}

\author{
Jennifer W. Mitchell Fetch, Katherine Stanley, Martin Entz, Stephen L. Fox, Dean Spaner, \\ Anne Kirk, Iris Vaisman, P.D. Brown, N. Ames, J. Chong, T.G. Jr. Fetch, S.M. Haber, C.A. McCartney, \\ J.G. Menzies, A. Tekauz, T.F. Townley-Smith, K.T. Nilsen, K.D. Hamilton, and D.A. Green
}

\begin{abstract}
AAC Oravena is a white-hulled spring oat (Avena sativa L.) cultivar selected and developed under organic management. AAC Oravena yields well under organic and conventional production systems, compared with check cultivars. AAC Oravena has good milling quality. AAC Oravena was registered (Reg. No. 7561) by the Variety Registration Office, Canada Food Inspection Agency, on 3 July 2014.
\end{abstract}

Key words: oat, Avena sativa L., cultivar description, milling oat, organic.

Résumé : AAC Oravena est un cultivar d'avoine (Avena sativa L.) à balle blanche élaboré sous le régime de culture biologique. AAC Oravena donne de bons rendements dans les systèmes de production biologiques et conventionnels, par rapport aux cultivars témoins. AAC Oravena a une bonne qualité meunière. Elle a été homologuée (numéro d'enregistrement 7561) par le Bureau d'Enregistrement des Variétés de l'Agence Canadienne d'Inspection des Aliments le 3 Juillet 2014. [Traduit par la Rédaction]

Mots-clés : avoine, Avena sativa L., description de cultivar, avoine de mouture, biologique.

\section{Introduction}

AAC Oravena is a white-hulled oat (Avena sativa L.) cultivar developed under organic management by Agriculture and Agri-Food Canada, Cereal Research Centre (AAFC$\mathrm{CRC}$ ), Winnipeg, $\mathrm{MB}$ in collaboration with the University of Manitoba, Winnipeg, MB. AAC Oravena was supported for registration at the Prairie Grain Development Committee Meeting in February 2013. It was registered (Reg. No. 7561) by the Variety Registration Office, Canada Food Inspection Agency on 3 July, 2014. AAC

Received 8 February 2021. Accepted 16 April 2021.

J.W. Mitchell Fetch, ${ }^{*}$ K.T. Nilsen, and D.A. Green. Agriculture and Agri-Food Canada, Brandon Research Centre, 2701 Grand Valley Road, Brandon, MB R7A 5Y3, Canada.

K. Stanley and M. Entz. Natural Systems Agriculture, Department of Plant Science, University of Manitoba, Winnipeg, MB R3T 2N2, Canada.

S.L. Fox. DL Seeds Inc., PO Box 1123, La Salle, MB R0G 1B0, Canada.

D. Spaner. Agricultural, Food and Nutritional Science, 4-10 Ag/Forestry Centre, University of Alberta, Edmonton, AB T6G 2P5, Canada.

A. Kirk. Manitoba Agriculture, Box 667, 65-3rd Avenue NE, Carman, MB R0G 0J0, Canada.

I. Vaisman. Organic Alberta, Unit\# 1, 10329-61 Ave, Edmonton, AB T6H 1K9, Canada.

P.D. Brown,* J. Chong,* S.M. Haber,* A. Tekauz,* and T.F. Townley-Smith.* Agriculture and Agri-Food Canada, Cereal Research Centre, Winnipeg, MB R3T 2M9, Canada.

N. Ames. Richardson Centre for Functional Foods and Nutraceuticals, 196 Innovation Drive, University of Manitoba Smart Park, Winnipeg, MB R3T 6C5 Canada.

T.G. Jr. Fetch* and J.G. Menzies. Agriculture and Agri-Food Canada, 101 Route 100, Morden, MB R6M 1Y5, Canada.

C.A. McCartney. Agriculture and Agri-Food Canada, 101 Route 100, Morden, MB R6M 1Y5, Canada; Natural Systems Agriculture, Department of Plant Science, University of Manitoba, Winnipeg, MB R3T 2N2, Canada.

K.D. Hamilton. Agriculture and Agri-Food Canada, University of Manitoba, E2-376 75A Chancellor's Circle, Winnipeg MB R3T 5V6, Canada.

Corresponding author: Jennifer W. Mitchell Fetch (email: jenfetch@hotmail.com).

*Retired.

(C) 2021 The Authors K. Stanley, M. Entz, D. Spaner, A. Kirk, and I. Vaisman, and the Crown. This work is licensed under a Creative Commons Attribution 4.0 International License (CC BY 4.0), which permits unrestricted use, distribution, and reproduction in any medium, provided the original author(s) and source are credited. 
Table 1. Grain yield $\left(\mathrm{kg} \cdot \mathrm{ha}^{-1}\right)$ of AAC Oravena (OT8003) and check cultivars in the 'B' Organic Test (BORG) for 2010 and 2012 in western Canada by soil zones.

\begin{tabular}{lllll}
\hline \multirow{5}{*}{ Soil zone } \\
\cline { 2 - 5 } Cultivar & Black $^{a}$ & $\begin{array}{l}\text { Black } \\
\text { and Grey }\end{array}$ & Brown $^{c}$ & Mean \\
\hline CDC Dancer & 3204.2 & 2665.4 & 3405.0 & 3091.5 \\
AC Morgan & 2893.1 & 3773.0 & 2764.4 & 3143.5 \\
Leggett & 3248.4 & 2833.4 & 3033.3 & 3038.4 \\
OT8003 & 3095.2 & 2928.8 & 3352.6 & 3125.5 \\
LSD $^{d}(P=0.05)$ & 410.6 & 565.0 & 731.5 & - \\
Significance & $\mathrm{ns}$ & $*$ & $\mathrm{~ns}$ & - \\
Station-years & 6 & 5 & 2 & 13 \\
\hline
\end{tabular}

Note: Significance at $P=0.05$ indicated as ns (not significant), or * (significant).

${ }^{a}$ Tests grown near Carman and Glenlea, MB (2010, 2012), Oxbow SK (2010), and Roblin MB (2012).

${ }^{b}$ Tests grown at Edmonton $\mathrm{AB}(2010,2012)$, Fort Vermilion and Lamont AB (2012), and Dawson Creek BC (2012).

${ }^{c}$ Tests grown near Kernen (2012) and Swift Current (2012) SK.

${ }^{d}$ Least significant difference (LSD) of means was based on the checks and OT8003 and calculated using the SAS PROC MIXED procedure (Saxton 1998).

Table 2. Summary of agronomic data for AAC Oravena (OT8003) and check cultivars in the 'B' Organic Test (BORG) for 2010 and 2012 in western Canada.

\begin{tabular}{|c|c|c|c|c|c|c|c|c|}
\hline Cultivar & $\begin{array}{l}\text { Days } \\
\text { to head }\end{array}$ & $\begin{array}{l}\text { Days } \\
\text { to mature }\end{array}$ & $\begin{array}{l}\text { Height } \\
(\mathrm{cm})\end{array}$ & $\begin{array}{l}\text { Lodging } \\
\text { resistance }^{a}(1-9)\end{array}$ & $\begin{array}{l}\text { Test weight } \\
\left(\mathrm{kg} \cdot \mathrm{hL}^{-1}\right)\end{array}$ & $\begin{array}{l}\text { Kernel } \\
\text { weight (mg) }\end{array}$ & $\begin{array}{l}\text { Plump } \\
(\%)^{b}\end{array}$ & $\begin{array}{l}\text { Thin } \\
(\%)^{c}\end{array}$ \\
\hline CDC Dancer & 54.8 & 93.4 & 92.9 & 3.9 & 51.8 & 30.7 & 82.3 & 17.7 \\
\hline Leggett & 55.2 & 96.2 & 87.8 & 2.6 & 52.2 & 33.9 & 78.7 & 21.4 \\
\hline OT8003 & 54.1 & 93.0 & 97.1 & 3.0 & 54.6 & 36.6 & 78.8 & 21.2 \\
\hline $\operatorname{LSD}^{d}(P=0.05)$ & 1.0 & 1.9 & 3.1 & 1.1 & 5.0 & 3.0 & 8.1 & 8.1 \\
\hline
\end{tabular}

Note: Significance at $P=0.05$ indicated as ns (not significant), or * (significant).

${ }^{a} 1$ no lodging; 9 completely lodged.

${ }^{b}$ Plump \% based on proportion of a 50-g sample remaining on top of a $2.18 \mathrm{~mm} \times 19.05 \mathrm{~mm}\left(51 / 2 / 64 \times 3 / 4^{\prime \prime}\right)$ sieve.

'Thin \% based on proportion of a 50-g sample passing through a $1.98 \mathrm{~mm} \times 19.05 \mathrm{~mm}(5 / 64 \times 3 / 4$ ") sieve.

${ }^{d}$ Least significant difference (LSD) of means was based on the checks and OT8003 and calculated using the SAS PROC MIXED procedure (Saxton 1998).

Oravena exhibits good yielding capacity and agronomic performance under organic management systems in the oat producing areas of western Canada. AAC Oravena is the first cultivar to be registered in Canada carrying the oat crown rust (Puccinia coronata Cda f. sp. avenae Eriks.) resistance gene Pc96. AAC Oravena was named by combining 'organic' with 'Avena'.

\section{Pedigree and Breeding Method}

AAC Oravena is a white-hulled $\mathrm{F}_{5}$-derived oat cultivar from a cross made in the fall-winter of 2004-2005 to combine improved yielding capacity with oat crown rust and stem rust (Puccinia graminis Pers. f. sp. avenae Eriks. and E. Henn.) resistance. The cross was made between two breeding lines, 04P01 and 99P26-BY1D. The line 04P01 was an $\mathrm{F}_{1}$ from the cross of AC Morgan/01RAT23 (Kibite and Menzies 2001), with the breeding line designated as 01RAT23 resulting from the cross of Pinnacle/ Pc96 (Mitchell Fetch et al 2003). The crown rust Pc96 single gene differential line is a selection derived from an Avena sativa accession from the Italian Gene Bank, Bari, Italy (Chong and Brown 1996). The paternal parent in the cross was 99P26-BY1D, which resulted from the 3-way cross of Riel/ND931475//HiFi (McKenzie et al 1986; McMullen et al 2005), in which HiFi has Pc91. 99P26BY1D carried resistance to oat crown rust, oat stem rust, 
and loose smut (Ustilago avenae (Pers.) Rostr). Thirteen $\mathrm{F}_{1}$ plants resulting from the final cross were grown in the greenhouse during the winter to the spring of 2005. Seven panicles were selected randomly from these plants, threshed individually, and the $F_{2}$ seed was planted in $3.4 \mathrm{~m}$ (11 feet) long panicle rows in the 2005 Organic Nursery grown under organically managed conditions on land at the University of Manitoba, Glenlea (UMG), MB. Lines grown at this location were exposed to natural disease infections of oat crown rust, oat stem rust, and barley yellow dwarf virus (BYDV), as well as competitive pressure from various weeds. The diseases may have blown westward across the highway from artificially inoculated AAFC plots. Rows were harvested individually at maturity and seed was sieved to obtain the plumpest seed. The plump $\mathrm{F}_{3}$ seed was used to plant two $3.4 \mathrm{~m}$ (11 feet) long rows in the 2006 Organic Nursery, under organic management at the UMG site. The $\mathrm{F}_{4}$ seed harvested from each of these rows was again sieved to produce the plumpest seed. This seed was utilized in spring of 2007 to plant two 12-row $2 \mathrm{~m} \times 6 \mathrm{~m}$ 'drill strip' plots on the UMG organically managed land. The seed produced from these two plots was bulked and sieved to obtain the plumpest filled seeds for planting a single $\mathrm{F}_{5}$ plot in 2008 , again on the organically managed land at the UMG site. Approximately 50 panicles were collected from mature, disease resistant, nonlodged plants within this plot. $\mathrm{F}_{6}$ seed from 42 selected panicles was sent for increase in two multi-seeded hills in the winter nursery of 2008-2009 near Palmerston North, New Zealand, under conventional management. Ten of these $\mathrm{F}_{5}$-derived $\mathrm{F}_{6}$ panicle plots were selected based on lodging resistance, acceptable height, crown and stem rust resistance, tolerance to BYDV, and plots producing $\geq 130 \mathrm{~g}$ of seed. Five of the highest yielding lines were selected for inclusion in the 2009 Preliminary Organic Yield trial, grown at two organically managed locations (University of Manitoba site at Glenlea and at Carman, MB) and one conventionally managed site (Portage la Prairie, MB), plus three artificially inoculated disease nurseries. Disease reaction nurseries were conducted on conventionally managed land, grown as hill plots at the University of Manitoba Point land in Winnipeg, Manitoba. These hill plots were artificially inoculated prior to planting with loose smut, and inoculated in early growth stages with oat crown rust and oat stem rust in separate nurseries. Each year, the crown rust inoculum was a composite of all the races collected from the annual survey in the previous year. For oat stem rust, an epidemic mixture of races FDJ, NGB, TDD, TGB, TGL, and TJJ (corresponding to North American stem rust races NA8, 16, 25, 27, 28, and 67, respectively; Fetch and Jin 2007) increased in a greenhouse was used. As well, a BYDV nursery was grown under conventional management at AAFC-CRC Glenlea, MB where virulent Rhopalosiphum padi (oat birdcherry aphid) non-specific isolate Y9301 (PAV-like) was

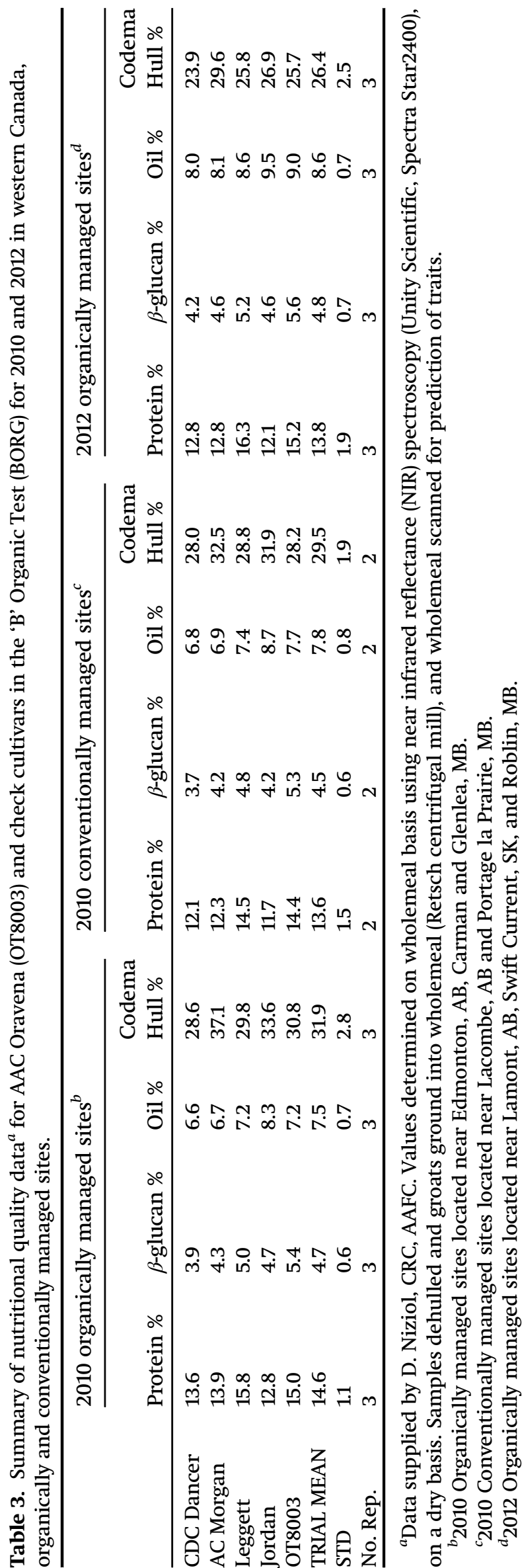

- Published by Canadian Science Publishing 
Table 4. Grain yield (kg.ha ${ }^{-1}$ ) of AAC Oravena (OT8003) and check cultivars in the Western Cooperative Oat Registration Test 2011-2012 in western Canada by soil zones.

\begin{tabular}{|c|c|c|c|c|c|}
\hline \multirow[b]{2}{*}{ Cultivar } & \multicolumn{5}{|c|}{ Soil zone } \\
\hline & Black $^{a}$ & $\begin{array}{l}\text { Black and } \\
\text { Grey }^{b}\end{array}$ & Brown $^{c}$ & Irrigated $^{d}$ & Mean \\
\hline CDC Dancer & 4186.9 & 5962.7 & 5329.7 & 6442.7 & 5480.5 \\
\hline AC Morgan & 4680.3 & 7110.0 & 5802.5 & 7500.6 & 6273.4 \\
\hline Leggett & 4751.8 & 5888.3 & 5924.0 & 6358.6 & 5730.7 \\
\hline OT8003 & 4757.0 & 6486.9 & 5941.6 & 5929.1 & 5778.7 \\
\hline $\operatorname{LSD}^{e}(P=0.05)$ & 347.8 & 369.1 & 507.9 & 658.6 & - \\
\hline Significance & $*$ & $*$ & * & $*$ & - \\
\hline Station-years & 11 & 7 & 7 & 2 & 27 \\
\hline
\end{tabular}

Note: Significance at $P=0.05$ indicated by ${ }^{*}$ (significant).

${ }^{a}$ Tests grown near Brandon (2012), Morden (2011, 2012), Portage la Prairie (2011, 2012), Indian Head (2011, 2012), Glenlea (2011, 2012), Oakbank (2012) MB and Melfort SK (2012).

${ }^{b}$ Tests grown at Beaverlodge $(2011,2012)$, Fort Vermilion (2011), Lacombe (2011, 2012) AB and Dawson Creek, BC (2011, 2012).

${ }^{c}$ Tests grown near Kernen (2011, 2012), Regina (2011), Swift Current (2011, 2012) and Watrous (2011, 2012) SK.

${ }^{d}$ Test grown under irrigation near Lethbridge, Alberta $(2011,2012)$.

${ }^{e}$ Least significant difference (LSD) of means was based on the checks and OT8003 and calculated using the SAS PROC MIXED procedure (Saxton 1998).

used to infect the young plants. Selections were made amongst the lines in the preliminary yield trial and compared with the check cultivars based on superior yield, disease resistance, and milling quality traits as measured by near infrared reflectance (NIR) spectroscopy on whole meal. Three lines performed well in this trial, and were entered into the 2010 B Organic Trial (BORG), grown at four locations across western Canada under organic management (University of Manitoba, Glenlea and Carman, MB; University of Manitoba, Oxbow, SK; University of Alberta West 240 site, Edmonton, AB) and at two conventionally managed sites (Portage la Prairie, $\mathrm{MB}$ and Lacombe, $\mathrm{AB}$ ), as well as in artificially inoculated disease nurseries as described above. Once again, selections were made based on superior performance for the combination of agronomic, disease resistance, and quality traits. One selection, 05P15-OA06, from this trial was entered into the 2011 Western Cooperative Oat Registration Trial (WCORT) as OT8003, and planted under conventional management at 16 sites across western Canada. OT8003 performed well enough in this trial to be entered for a second year of testing in the 2012 WCORT.

Agronomic yield trials also were conducted under organically managed systems, or with no added nutrients or pesticides, at nine locations in the 2012 BORG (Carman, Notre Dame, and Roblin, MB; Kernen and Swift Current, SK; Edmonton, Lamont, and Fort Vermilion, AB; Dawson Creek, BC). Seedling reactions to specific races of oat crown rust and oat stem rust were also evaluated in greenhouses at Winnipeg, MB concurrent to the BORG and WCORT. Means separation and LSD were calculated utilizing the SAS PROC Mixed Macro (Saxton 1998).

One hundred eighty panicles were selected at random from a rogued $\mathrm{F}_{8}$ increase plot grown at AAFC-CRC, Glenlea, MB, under conventional management in 2010. Seed threshed from each single panicle was planted in plots of paired 1-m rows in isolation near Glenlea, MB in 2011, under conventional management. One hundred seventy-four uniform lines were selected to provide seed for 15-m-long rows produced at Indian Head, SK in 2013. Of these, 151 rows were selected based on uniformity and the seed produced was bulked to form the breeder seed for AAC Oravena.

\section{Performance}

\section{Area of adaptation}

Based on agronomic and disease resistance testing, AAC Oravena is suitable for organic production systems in western Canada. Across the two years of testing (2010 and 2012), there was no significant difference in yield from the checks in the Black and Brown soil zones (zones 1 and 3) (Table 1). AAC Oravena yielded more than Leggett and CDC Dancer in the Black and Grey soil zone (zone 2), and better than Leggett and AC Morgan in the Brown soil zone. (Table 1). Under organic conditions across western Canada in 2012, AAC Oravena had 3.5\% higher yield than Leggett, and out-yielded the highyielding AC Morgan check at 4 of 9 organically managed 


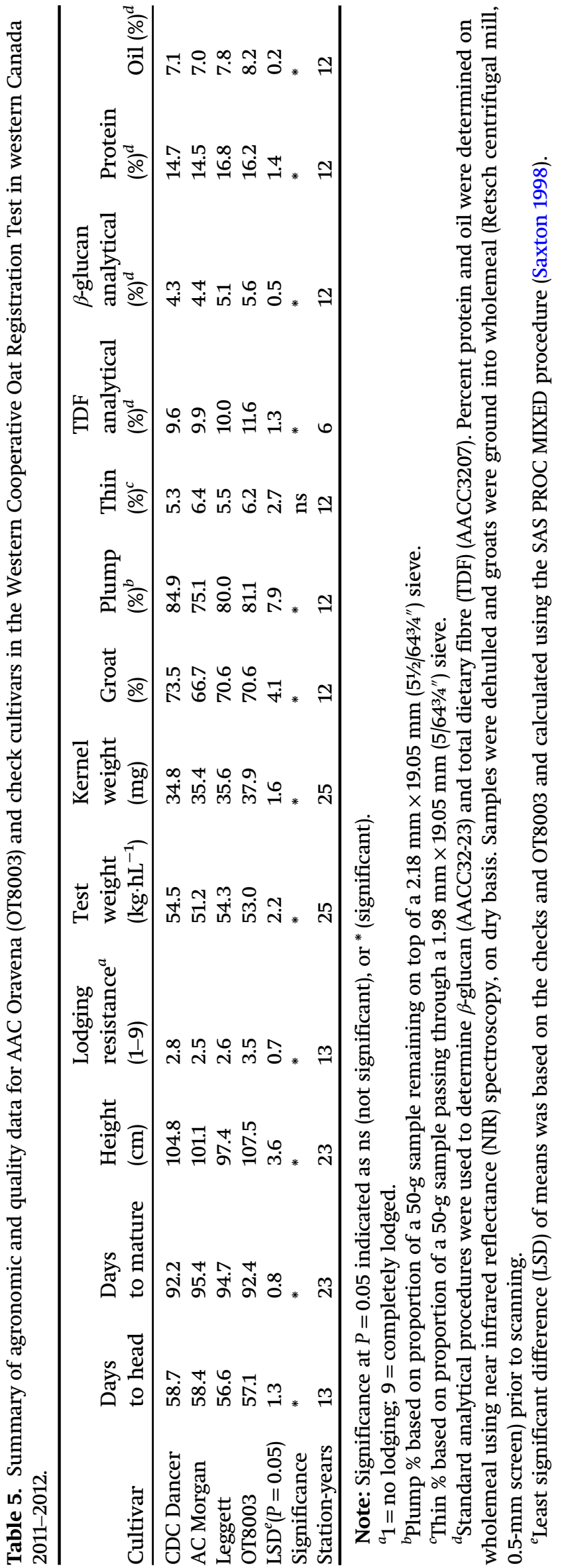

sites (data not presented). AAC Oravena headed significantly earlier than AC Morgan and Leggett, and had earlier maturity than all of the checks, but the difference was not significant from the maturity of CDC Dancer (Table 2). AAC Oravena was significantly taller than the checks, but had superior lodging resistance to AC Morgan. AAC Oravena had the highest test weight of all of the organically tested lines, and was significantly higher than AC Morgan. The thousand kernel weight of AAC Oravena was significantly higher than CDC Dancer and AC Morgan. In 2010, AAC Oravena had higher betaglucan (BG) than all of the checks, and had protein, oil and hull content similar to Leggett (Table 3). In 2012, AAC Oravena had higher BG than the checks, with protein content lower and oil content higher than Leggett, but similar hull content (Table 3).

Under conventional management systems in 2011 and 2012, AAC Oravena was not significantly different from AC Morgan in yield, except in the Black and Grey soil zone (zone 2) and at the irrigated site near Lethbridge, AB (zone 4) (Table 4). AAC Oravena headed significantly earlier than CDC Dancer, but later than Leggett (Table 5). AAC Oravena matured significantly earlier than AC Morgan and Leggett. AAC Oravena had significantly higher thousand kernel weight and higher total dietary fibre (TDF) than the checks. AAC Oravena had significantly higher betaglucan (BG) and percent protein than CDC Dancer and AC Morgan. The oil content of AAC Oravena was significantly higher than that of the checks (Table 5).

\section{Disease reaction}

AAC Oravena is resistant to loose smut, and had slightly better resistance to BYDV than the checks. Crown rust infection was sporadic and spotty in the nurseries the final three years of testing for AAC Oravena. In the 2010 and 2012 BORG tests, AAC Oravena was resistant (0 or $\mathrm{R}$ reaction), while the AC Morgan susceptible check had field crown rust reactions of $20 S-30 S$ and 20MSS, respectively (data not presented). In the 2011 and 2012 WCORT tests, the crown rust infection was again light and AC Morgan had low levels (2MS or $2 S$ ), so it was not useful as a susceptible check (Table 6). Additional data for AAC Oravena in other tests under higher crown rust pressure showed it does possess effective resistance (Table 7).

Based on the parentage, genes Pc96 or Pc91 (from HiFi) or genes Pc38, Pc39, or Pc68 (from AC Pinnacle) could be present in AAC Oravena. In seedling tests, AAC Oravena was resistant to all crown rust isolates, including CR259 (Table 6). CR259 (LQCB-91) is virulent to Pc38, Pc39 and Pc91, and avirulent to Pc96. Therefore, the resistance expressed by AAC Oravena to CR259 is probably conditioned by Pc96. However, Pc91 could still be present in AAC Oravena, but not detected, because its susceptible reaction to CR259 would be masked by the epistatic effect of the resistance reaction of Pc96. Further tests on 
Table 6. Summary of disease reactions for AAC Oravena (OT8003) and check cultivars in the Western Cooperative Oat Registration Test 2011-2012.

\begin{tabular}{|c|c|c|c|c|c|c|c|c|c|c|c|c|c|c|c|c|c|c|}
\hline \multirow[b]{2}{*}{ Cultivar } & \multicolumn{4}{|l|}{ Field ratings } & \multicolumn{8}{|c|}{ Seedling reaction to selected races of oat crown rust ${ }^{e}$} & \multicolumn{6}{|c|}{$\begin{array}{l}\text { Seedling reaction to selected races of oat stem } \\
\text { rust }^{f}\end{array}$} \\
\hline & $\operatorname{BYDY}^{a}(1-9)$ & $\begin{array}{l}\text { Loose } \\
\text { Smut }^{b} \%\end{array}$ & $\mathrm{OCR}^{c}$ & $\mathrm{OSR}^{d}$ & $\begin{array}{l}\text { CR13 } \\
\text { SJQL-96 }\end{array}$ & $\begin{array}{l}\text { CR223 } \\
\text { NGCB-94 }\end{array}$ & $\begin{array}{l}\text { CR241 } \\
\text { DSGB }\end{array}$ & $\begin{array}{l}\text { CR249 } \\
\text { DQBG-94 }\end{array}$ & $\begin{array}{l}\text { CR254 } \\
\text { LRBG }\end{array}$ & $\begin{array}{l}\text { CR257 } \\
\text { BRBG-94 }\end{array}$ & $\begin{array}{l}\text { CR258 } \\
\text { NTGG }\end{array}$ & $\begin{array}{l}\text { CR259 } \\
\text { LQCB-91 }\end{array}$ & $\begin{array}{l}\text { NA8 } \\
\text { FDJ }\end{array}$ & $\begin{array}{l}\text { NA16 } \\
\text { NGB }\end{array}$ & $\begin{array}{l}\text { NA25 } \\
\text { TDD }\end{array}$ & $\begin{array}{l}\text { NA27 } \\
\text { TGB }\end{array}$ & $\begin{array}{l}\text { NA28 } \\
\text { TGL }\end{array}$ & $\begin{array}{l}\text { NA67 } \\
\text { TJJ }\end{array}$ \\
\hline \multicolumn{19}{|c|}{2011 Western Coop } \\
\hline $\begin{array}{l}\mathrm{CDC} \\
\text { Dancer }\end{array}$ & $7.8 \mathrm{~S}$ & 0 & $\operatorname{Tr}$ & $5 \mathrm{I}$ & 0 & 0 & 4 & 4 & 4 & 4 & 4 & ;1(4) & ;1- & $11+$ & $1-$ & $; 1$ & $11+$ & $33+$ \\
\hline $\begin{array}{l}\text { AC } \\
\quad \text { Morgan }\end{array}$ & $7.3 \mathrm{~S}$ & 16 & 2 MS & 50 MSS & 4 & 4 & 4 & 4 & 4 & 4 & 4 & 4 & $3-3$ & $33+$ & $3-$ & $33+$ & $3-$ & $33+$ \\
\hline Leggett & $8.1 \mathrm{~S}$ & 0 & $\mathrm{R}$ & $3 \mathrm{I}$ & 0 & 0 & 0 & 0 & 0 & 4 & 0 & 0 & $; 1$ & $; 1$ & $2+$ & $; 1$ & $1-$ & $33+$ \\
\hline OT8003 & $6.8 \mathrm{~S}$ & 0 & $\mathrm{R}$ & $25 \mathrm{I}$ & 0 & 0 & 0 & 0 & 0 & ;f & ; & 0 & ;1- & $; 1$ & $; 1-$ & $; 1$ & 0 & $12+$ \\
\hline \multicolumn{19}{|c|}{2012 Western Coop } \\
\hline $\begin{array}{l}\text { CDC } \\
\text { Dancer }\end{array}$ & $6.9 \mathrm{~S}$ & 0 & $\operatorname{Tr} S$ & $25 \mathrm{I}$ & 0 & 0 & 4 & 4 & 0 & 4 & 4 & $;(4)$ & 0 & $1-$ & $1-$ & $1-1$ & $12-$ & $33+$ \\
\hline $\begin{array}{l}\text { AC } \\
\text { Morgan }\end{array}$ & $6.6 \mathrm{~S}$ & 15 & $2 S$ & $70 \mathrm{~S}$ & 4 & 4 & 4 & $4 \mathrm{f}$ & 4 & 4 & 4 & 4 & $3+$ & $33+$ & 4 & 34 & 4 & $33+$ \\
\hline Leggett & $6.8 \mathrm{~S}$ & 0 & $\mathrm{R}$ & $50 \mathrm{MS}$ & 0 & 0 & 0 & 0 & 0 & 4 & 0 & 0 & ;1- & ;1- & $1-$ & 1 & $11+$ & $33+$ \\
\hline OT8003 & $5.3 \mathrm{I}$ & 0 & $\operatorname{Tr} S / 10 \mathrm{MS}$ & $40 \mathrm{I}$ & 0 & 0 & 0 & 0 & ; & ; & ; & $4 / 0$ & $2(1-1) 1(12-)$ & ;1- & $1-1$ & 1 & 1 & $12-$ \\
\hline
\end{tabular}

${ }^{a}$ Virulent Rhopalosiphum padi non-specific isolate Y9301 (PAV-like) was used. Barley yellow dwarf (BYD) virus readings were taken at mid-dough using 1-9 (best-worst) scale; $\mathrm{R}=1-3.5$; MR = 3.51-4.5; MR-MS or I = 4.51-5.5; MS = 5.51-6.5; $\mathrm{S}=6.51-9.0$.

${ }^{b}$ Smut data: a mixture of three races of Black Loose Smut [Ustilago avenae (Pers.) Rostr.], A13, A60 and A617, was used as inoculum.\% infection. $\mathrm{R}=0 \%-15 \%$; $\mathrm{MR}=16 \%-35 \%$; MR-MS $=36 \%-55 \%$; MS $=56 \%-75 \%$; $>75 \%$.

${ }^{c}$ Oat crown rust (OCR): field ratings based on artificial inoculation with composite of isolates bulked from the previous year annual crown rust survey in Manitoba.

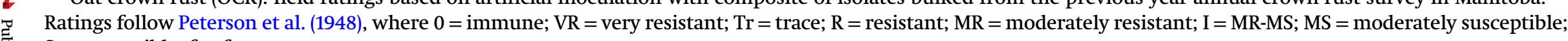
$\mathrm{S}=$ susceptible; $\mathrm{f}$, a few.

${ }^{d}$ Oat stem rust (OSR): field ratings based on reaction to an artificially inoculated mixture of races (NA8, 16, 25, 27, 28, 55 and NA67). Ratings follow Peterson et al. (1948) as listed above.

${ }^{e}$ OCR greenhouse ratings: all entries were inoculated with selected races of crown rust in greenhouse seedling tests. Ratings follow Stakman et al. (1962).

${ }^{f}$ OSR greenhouse ratings: all entries were inoculated with seven selected races of stem rust in greenhouse seedling tests. Ratings follow Stakman et al. (1962). 
Table 7. Summary of oat crown rust severities in field nurseries over years.

\begin{tabular}{llllll}
\hline Year & AAC Oravena & Pc96 & Pc91 & HiFi & AC Morgan/Makuru \\
\hline 2009 & 0 & $0-5 M S$ & 0 & 0 & $50 \mathrm{MS}-80 \mathrm{~S}$ \\
2010 & 0 & trS & $2 \mathrm{~S}-5 \mathrm{~S}$ & $0, \mathrm{trS}$ & $70 \mathrm{~S}-80 \mathrm{~S}$ \\
2011 & $\mathrm{R}$ & $\mathrm{R}$ & $\mathrm{R}$ & $\mathrm{R}$ & $30 \mathrm{~S}$ \\
2013 & $1 \mathrm{MR}-5 \mathrm{MS}$ & $20 \mathrm{MS}$ & $1 \mathrm{MR}$ & $5 \mathrm{MR}$ & $20 \mathrm{MS}-40 \mathrm{MS}$ \\
2014 & trS & $1 \mathrm{MS}$ & $3 \mathrm{MS}$ & $3 \mathrm{MS}$ & $20 \mathrm{~S}-40 \mathrm{~S}$ \\
2019 & $5 \mathrm{MR}$ & $1 \mathrm{MR}$ & $14 \mathrm{~S}$ & $20 \mathrm{~S}$ & $8 \mathrm{MS}$ \\
\hline
\end{tabular}

Note: Oat crown rust (OCR): field ratings based on artificial inoculation with composite of isolates bulked from the previous year annual crown rust survey in Manitoba. Ratings follow Peterson et al. (1948), where $0=$ immune; VR = very resistant; $\mathrm{Tr}=$ trace; $\mathrm{R}=$ resistant; $\mathrm{MR}=$ moderately resistant; $\mathrm{I}=\mathrm{MR}-\mathrm{MS}$;

MS = moderately susceptible; $\mathrm{S}=$ susceptible.

AAC Oravena with isolates avirulent and virulent to Pc91 and Pc96 would provide a more definitive answer.

AAC Oravena is thus the first oat cultivar to carry Pc96 registered in Canada. This gene remains effective to the prevalent races in the prairie population since it was first tested in 1996 (Chong and Brown 1996). The resistance gene Pc91 was highly effective until 2011, after which a shift occurred in the crown rust pathogen population, with virulence to Pc91. By 2015 , over $67 \%$ of the isolates in the rust population were virulent to this gene (Menzies et al. 2019). The susceptible reaction of HiFi and Pc91 in the nurseries in 2019 (Table 7) was a result of this virulence shift. In contrast, the level of resistance for AAC Oravena and Pc96 remained unchanged from that of previous years (Table 7), further supporting the conclusion that Pc96 is present in AAC Oravena and it is this gene that is providing protection.

AAC Oravena had an intermediate reaction to oat stem rust in field inoculated nurseries, and a resistant seedling reaction to specific pathotypes including TJJ (NA67). AAC Oravena may carry novel resistance to TJJ, as in three years of seedling testing, the infection type (IT) was 12- (Tables 6 and 7). Based upon data obtained in 2011 and again in 2018, AAC Oravena has resistance to Fusarium head blight, through lower accumulation of Deoxynivalenol (DON), similar to Leggett (data not shown).

\section{Other Characteristics}

\section{Seedling characteristics}

Coleoptile colour: Green.

Hypocotyl length (basal internode): Long.

Juvenile growth habit: Erect to semi-erect.

Seedling leaves: Leaf blades are glabrous, leaf sheath is glabrous.

Tillering capacity: Intermediate.

\section{Adult plant characteristics}

Flag leaf length: $1.7 \mathrm{~cm}$ longer than HiFi.

Upper culm node: Slightly pubescent to pubescent.

Maturity: Similar to HiFi.

Plant height: $2.3 \mathrm{~cm}$ taller than HiFi.

Lodging resistance: Fair.
Panicle characteristics

Shape: Equilateral.

Length: Medium.

Density: Intermediate.

Panicle branches: Medium, semi-erect to horizontal. 8-10 panicle branches with 5 whorls Lower panicle whorl attached to the first node; lower panicle nodes have no hairs.

Rachis: Straight, secondary rachis node absent.

Rachilla: Glabrous; medium long; medium width; absent to mid-deep grooves.

\section{Spikelet characteristics}

Attitude: Semi-nodding to nodding.

Number of florets: Two or less.

Spikelet separation: Fracture.

Glumes: Medium length and width.

\section{Kernel characteristics}

Size: Medium long, medium width.

Colour: White to cream.

Shape: Mid-plump.

Basal hairs: Absent.

Lemma colour: White to cream.

Lemma awns: Very infrequent to infrequent.

Palea length: Medium to long.

\section{Maintenance and Distribution of Pedigreed Seed Stocks}

Breeder seed of AAC Oravena will be maintained by the Seed Increase Unit, Agriculture and Agri-Food Canada, Research Farm, Indian Head, Saskatchewan, Canada, SOG 2K0. Multiplication and distribution of pedigreed seed will be through Grain Millers Inc., 1 Grain Millers Drive, Yorkton, SK S3N $3 Z 4$.

\section{Acknowledgments}

We gratefully acknowledge funding and research grants provided by Agriculture and Agri-Food Canada (AAFC), the Organic Science Clusters (Organic Agriculture Centre of Canada and the Organic 
Federation of Canada), including Grain Millers Inc. and Prairie Oat Growers Association (POGA). The Prairie Oat Breeding Consortium (POBC) is also acknowledged for their continued funding. Thanks to the technical staff at all of the locations for their support in developing this cultivar.

\section{References}

Chong, J., and Brown, P.D. 1996. Genetics of resistance to Puccinia coronata f. sp. avenae in two Avena sativa accessions. Can. J. Plant Pathol. 18: 286-292. doi:10.1080/07060669609500626.

Fetch, T.G., and Jin, Y. 2007. Letter Code System of Nomenclature for Puccinia graminis f. sp. avenae. Plant Dis. 91 (6): 763-766. doi:10.1094/PDIS-91-6-0763. PMID:30780488.

Kibite, S., and Menzies, J.G. 2001. AC Morgan oat. Can. J. Plant Sci. 81: 85-87. doi:10.4141/P00-075.

McKenzie, R.I.H., Brown, P.D., Harder, D.E., Chong, J., Nielsen, J., Haber, S., et al. 1986. Registration of 'Riel' Oat. Crop Sci. 26(6): 1256. doi:10.2135/cropsci1986.0011183X002600060040x
McMullen, M., Doehlert, D.C., and Miller, J.D. 2005. Registration of 'HiFi' Oat. Crop Science 45(4): 1664. doi:10.2135/ cropsci2005.003

Menzies, J.G., Xue, A., Gruenke, J., Dueck, R., Deceuninck, S., and Chen, Y. 2019. Virulence of Puccinia coronata var avenae f. sp. avenae (oat crown rust) in Canada during 2010 to 2015. Can. J. Plant Pathol. 41: 379-391. doi:10.1080/07060661.2019. 1577300.

Mitchell Fetch, J.W., Brown, P.D., Duguid, S.D., Chong, J., Haber, S.M., Menzies, J.G., et al. 2003. Pinnacle oat. Can. J. Plant Sci. 83: 97-99. doi:10.4141/P02-017.

Peterson, R.F., Campbell, A.B., and Hannah, A.E. 1948. A diagrammatic scale for estimating rust intensity on leaves and stems of cereals. Can. J. Res. Sect. C. 26: 496-500. doi:10.1139/cjr48c-033.

Saxton, A.M. 1998. A macro for converting mean separation output to letter groupings in Proc Mixed. Proc. 23rd SAS Users Group Intl., SAS Institute, Cary, NC, pp. 1243-1246.

Stakman, E.C., Stewart, D.M., and Loegering, W.Q. 1962. Identification of physiologic races of Puccinia graminis $\mathrm{f}$. $\mathrm{sp}$. tritici. USDA-ARS Publ. E-617, St. Paul, MN. 